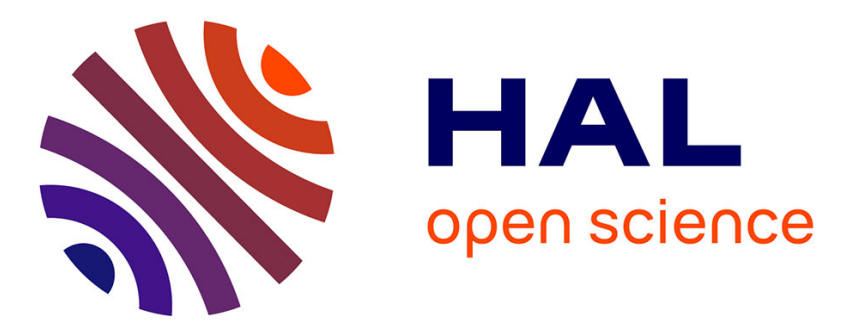

\title{
Linkage between RFLP molecular markers and the dwarfing genes Rht-B1 and Rht-D1 in wheat
}

Pierre Sourdille, Gilles Charmet, Maxime M. Trottet, Marie-Hélène Tixier, Christiane Boeuf, Sylvie Negre, Dominique D. Barloy, Michel M. Bernard

\section{> To cite this version:}

Pierre Sourdille, Gilles Charmet, Maxime M. Trottet, Marie-Hélène Tixier, Christiane Boeuf, et al.. Linkage between RFLP molecular markers and the dwarfing genes Rht-B1 and Rht-D1 in wheat. Hereditas, 1998, 128 (1), pp.41-46. 10.1111/j.1601-5223.1998.00041.x . hal-02698624

\section{HAL Id: hal-02698624 https://hal.inrae.fr/hal-02698624}

Submitted on 1 Jun 2020

HAL is a multi-disciplinary open access archive for the deposit and dissemination of scientific research documents, whether they are published or not. The documents may come from teaching and research institutions in France or abroad, or from public or private research centers.
L'archive ouverte pluridisciplinaire HAL, est destinée au dépôt et à la diffusion de documents scientifiques de niveau recherche, publiés ou non, émanant des établissements d'enseignement et de recherche français ou étrangers, des laboratoires publics ou privés. 


\title{
Linkage between RFLP molecular markers and the dwarfing genes $R h t-B 1$ and $R h t-D 1$ in wheat
}

\author{
P. SOURDILLE ${ }^{1}$, G. CHARMET ${ }^{1}$, M. TROTTET ${ }^{2}$, M. H. TIXIER ${ }^{1}$, C. BOEUF ${ }^{1}$, S. NÈGE ${ }^{1}$, \\ D. BARLOY ${ }^{2}$ and M. BERNARD ${ }^{1}$ \\ ${ }^{1}$ INRA Station d'Amélioration des Plantes, Domaine de Crouël, 63039 Clermont-Ferrand CEDEX, France \\ ${ }^{2}$ INRA Station d'Amélioration des Plantes. Domaine de la Motte, 35653 Le Rheu CEDEX, France
}

\begin{abstract}
Sourdille, P., Charmet, G., Trottet, M., Tixier, M. H. Boeuf, C., Nègre, S., Barloy, D. and Bernard, M. 1998. Linkage between RFLP molecular markers and the dwarfing genes Rht-B1 and Rht-Dl in wheat - Hereditas 128: 41-46. Lund, Sweden. ISSN 0018-0661. Received June 20, 1997. Accepted November 5, 1997

Identifying genotypes carrying the dwarfing genes $R h t-B 1$ and $R h t-D 1$ would be of great interest for wheat (Triticum aestivum L. em Thell) breeding. Two RFLP loci were found to be linked to those two genes, $X p s r$ 144-4B with $R h t-B 1$ on chromosome 4BS and $X g l k 578-4 D$ with $R h t-D 1$ on chromosome 4DS, by genotyping two $F_{2}$ populations, Renan $(R h t-B 1 b) \times$ Camp-Rémy and Rendez-Vous $(R h t-D 1 b) \times$ Roazon. Utilisation of these markers in breeding schemes is discussed.
\end{abstract}

Michel Bernard, INRA Station d'Amélioration des Plantes, Domaine de Crouël, 63039 Clermont-Ferrand CEDEX, France

Reducing plant height in wheat is of great economical importance because it makes it possible to simultaneously increase lodging resistance, and thus stability of yield, and harvest index. Because many genetic factors which influence development, morphology or vigour will have effects on final plant height, this character involves most of the 21 chromosomes in wheat (SNAPE et al. 1977). Several genes have already been identified and "short" alleles have been designated Rht (for Reduced height) relative to their "tall" alleles $r h t$. The Norin 10 dwarfing alleles $R h t 1$ and $R h t 2$ have been used extensively in the breeding schemes during the last 40 years due to the lack of consequences on yielding ability. In CIMMYT, BoRLAUG (1968) made the first successful crosses between Norin 10-Brevor 14 and tall "daylength insensitive" wheats in 1955. The varieties Pitic 62 and Penjamo 62 were released to Mexican farmers in 1962. Since the registration in 1964 of the semi-dwarf variety 'Gaines' (VOGEL 1964), the proportion of varieties carrying dwarfing alleles is in constant increase and, at the present time, reaches more than $80 \%$ of the world registrations.

Dwarf wheat plants are classified into two groups following their reaction to the application of exogenous gibberellin (GA; REID 1986). The GA insensitive character of Norin 10 was first mentioned by ALLAN et al. (1959), and genes influencing this trait were named Gai (for GA insensitivity; MCINTOSH 1979). Genetic linkage analysis between Rht 1 and Gail on one hand, and Rht 2 and Gai2 on the other, made by Gale and Marshall (1975) and Gale and GREGORY (1977) showed absence of recombination. It was considered that the Rht and Gai genes were identical and that they conferred, by pleiotropic effects, both reduced height and gibberellin insensitivity (WORLAND et al. 1987). Rht 1 and $R h t 2$ act by reducing internode length without reducing spike morphology (ALLAN et al. 1968). Both are semi-dominant (GALE and YoUSSEFIAN 1985) and have similar effects on plant height (reduction of about $20 \mathrm{~cm}$ ) even though Rht 2 seems to have a stronger effect than Rht1 (Allan 1970; BörNer et al. 1993). Numerous alleles inducing different levels of dwarfism have already been identified for either Rht 1 by GALE et al. (1975; Rht3), WorLAND and PETROVIC (1988; Rht $1 S)$, WORLAND and SAYERS (1995; Rht $1(B . d w)$ ), or Rht 2 by BÖRNER and METTIN (1988; Rht 10).

Combination of Rht 1 and Rht 2 in the same genotype generally produces a strong effect on plant height which, most of the time, induces a decrease of the agronomical value of the variety (ALLAN 1983). In addition, crosses between lines carrying different dwarfing genes generate a wide segregation for height which leads to the rejection of the majority of the plants only because they are too tall or too short. It would then be advisable to cross lines with the same dwarfing gene, especially for recurrent breeding. A large variation in height reduces the efficiency of breeding because of strong competition effects between tall and short plants resulting in difficulties in evaluating populations segregating for height. Unfortunately, the test using GA is unable to distinguish the lines carrying Rht 1 from those with Rht 2 . Test crosses with lines from a known genotype (Rht 1 or Rht2) must be done to identify the gene(s) of new lines.

Since 1989, dense RFLP linkage maps of the hexaploid wheat Triticum aestivum L. em. Thell. have been developed from interspecific crosses for the ho- 
moeologous groups 1 (VAN DEYNZE et al. 1995), 2 (Devos et al. 1993; Nelson et al. 1995a), 3 (Devos et al. 1992; Nelson et al. 1995b), 4 and 5 (XIE et al. 1993; Devos et al. 1995; Nelson et al. 1995c), 6 (JIA et al. 1996; MARINO et al. 1996) and 7 (CHAO et al. 1989; NELSON et al. 1995c) and from an intervarietal cross (CADALEN et al. 1997). These maps would be useful to identify markers linked to $R h t l$ and to $R h t 2$ for an accurate selection of the plants having these dwarf alleles. Previous studies indicate that these two genes are carried on the short arms of the homoeologous group 4. Using telocentric mapping, it was shown that $R h t 1$ is located at 13 map units from the centromere on chromosome 4BS while Rht 2 falls 15 map units from the centromere on the chromosome 4DS (MCVITTIE et al. 1978).

The aim of this study was to look for markers linked to these two genes, using segregation in two $F_{2}$ populations. We have thus focused our study on chromosomes $4 \mathrm{~B}$ and 4D. In the present study, we will use the conventional and newly proposed nomenclature of the GA insensitive $R h t$ alleles in wheat (BöRNER et al. 1996) i.e., Rht-Bla and Rht-Dla (formerly $r h t 1$ and $r h t 2$ ) and $R h t-B 1 b$ and $R h t-D 1 b$ (formerly $R h t 1$ and $R h t 2$ ).

\section{MATERIAL AND METHODS}

\section{Plant material}

Two $F_{2}$ populations were elaborated at the INRA Plant Breeding Station at Rennes. The first one, of 116 plants, was from the cross between the cultivars Renan (Rht-B1b) and Camp-Rémy, and height was ranging between 58 and $105 \mathrm{~cm}$. The second one, of 115 individuals, was produced from the cross between the cultivars Rendez-Vous (Rht-D1b) and Roazon, and height was ranging between 61 and $127 \mathrm{~cm}$.

\section{Plant height evaluation}

Plant height of $F_{2}$ plants and of the four parents (Renan, Camp-Rémy, Rendez-Vous, Roazon) was scored under field conditions at INRA Station at Rennes in 1995. The genotype at the loci $X R h t-B I$ and $X R h t-D 1$ was determined in the greenhouse in 1996 on $F_{3}$ seedlings, using a method derived from that of GALE and GREGORY (1977). Two replications of 20 seeds were sown in wet sand in seed trays and placed into controlled environments to ensure even germination and to avoid etiolation. The seeds were then irrigated once a day with a solution containing $5 \mathrm{mg} / \mathrm{l}$ of $\mathrm{GA}_{3}$. Measurements were taken 12-15 days after sowing, and plantlets were divided into two groups. Those homozygous for $R h t-B 1 b$ or $R h t-D l b$ ("short" alleles) present short sheaths and first leaves, while those heterozygous (Rht-Bla/Rht-Blb or Rht$D 1 a / R h t-D 1 b)$ or homozygous for $R h t-B 1 a$ or $R h t$ Dla ("tall" alleles) have long sheaths and first leaves twice as long as short plants.

\section{Molecular markers and RFLP analysis}

The probes used in this study are given in Table 1. The techniques for DNA extraction, digestion, electrophoresis, blotting, and hybridization were described by CADALEN et al. (1997). The protocol using non-radioactive probes was detailed in $\mathrm{LU}$ et al. (1994) and SourdiLLE et al. (1996).

One microsatellite (GWM165; PLASCHKE et al. 1996) was also mapped on these populations. PCR reactions were carried out in a final volume of $50 \mu \mathrm{l}$ in a Perkin-Elmer 9600 thermocycler. The reaction buffer contained $100 \mathrm{ng}$ of template DNA, $0.2 \mathrm{mM}$ of each deoxynucleotide, $1.5 \mathrm{mM} \mathrm{MgCl} 2,500 \mathrm{nM}$ of each primer, and 1 unit of Taq-DNA-polymerase (Boehringer). Thirty-five cycles with $1 \mathrm{~min}$ at $96^{\circ} \mathrm{C}$, $1 \mathrm{~min}$ at $60^{\circ} \mathrm{C}$ (in some cases $57^{\circ} \mathrm{C}$ ), and $2 \mathrm{~min}$ at $72^{\circ} \mathrm{C}$ were realised, followed by a final elongation step of $10 \mathrm{~min}$ at $72^{\circ} \mathrm{C}$. Polyacrylamide $(6 \%)$ denaturing gels $(0.4 \mathrm{~mm}$ thick) were prepared with $1 \mathrm{X}$ TBE buffer $(90 \mathrm{mM}$ Tris, $90 \mathrm{mM}$ boric acid, $2 \mathrm{mM}$ EDTA, pH 8.2) and cast between glass plates, one previously treated with Sigmacote (Sigma) and the other with Silane A-174 (Sigma). From each sample, $1.6 \mu \mathrm{l}$ were loaded together with $0.8 \mu \mathrm{l}$ of loading buffer $(10 \mathrm{mM} \mathrm{NaOH}, 0.05 \%$ bromophenol blue, $0.05 \%$ xylen cyanol, in $95 \%$ deionized formamide) after a 5 min denaturation in boiling water. Samples were then run for $2 \mathrm{~h}$ at $2000 \mathrm{~V}, 36 \mathrm{~mA}$ and $61 \mathrm{~W}$. DNA was revealed by a silver staining method derived from the protocol of BASSAM et al. (1991). The gel was first fixed for 20 min in $10 \%$ acetic acid, rinsed three times with water and stained in a solution containing $0.1 \%$ silver nitrate and $0.05 \%$ formaldehyde for $30 \mathrm{~min}$. After a quick rinse (not exceeding $10 \mathrm{~s}$ ) microsatellites were revealed by adding the developer (3\% sodium carbonate, $0.05 \%$

Table 1. DNA probes and microsatellites used in this study

\begin{tabular}{ll}
\hline Probes & References \\
\hline GLK335 & LIU and TSUNEWAKI (1991) \\
GLK556 & LIU and TSUNEWAKI (1991) \\
GLK578 & LIU and TSUNEWAKI (1991) \\
GWM165 & PLASCHKE et al. (1996) \\
PSR144 & GALE et al. (1995) \\
FBA41 & QUETIER (personal gift) \\
FBA177 & QUETIER (personal gift) \\
FBA211 & QUETIER (personal gift) \\
FBB58 & QUETIER (personal gift) \\
\hline
\end{tabular}




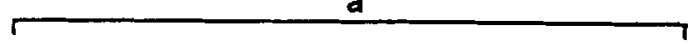

$4 B$

$4 \mathrm{D}$

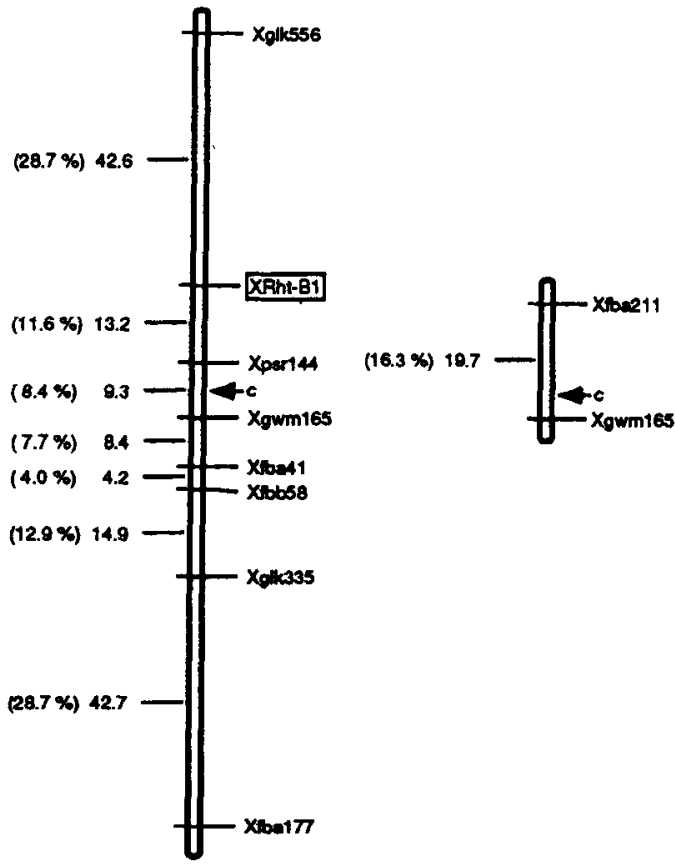

b

$4 B$

4D

Fig. 1. Maps of wheat chromosomes $4 B$ and $4 D$ obtained from the $F_{2}$ populations Renan $\times$ Camp-Remy (a) and Rendez-Vous $\times$ Roazon (b). Markers are in LOD 3.0 order. Distances on the left of the chromosome are in CM according to KosAMBI (1944) and numbers in brackets indicate recombination values. Approximate position of the centromere (c) is indicated with an arrow.

formaldehyde, $2 \mathrm{mg} / \mathrm{l}$ sodium thiosulfate). Image development was conducted at a maximum temperature of $12^{\circ} \mathrm{C}$ during 3 to $10 \mathrm{~min}$. The reaction was stopped by addition of acetic acid (10\%), and the gel was rinsed in water and dried at room temperature.

\section{Mapping and linkage analysis}

The maps obtained from the $F_{2}$ populations were constructed using Mapmaker/exp version 3.06 (LANDER et al. 1987). The linkage groups were established by calculating recombination frequencies with the following conditions: thresholds for $\mathrm{LOD}=3$ and $\theta=0.35$. Association between molecular markers and plant height (QTLs) was evaluated by the "marker regression" method (KEARSEY and HYNE 1994) computed with Splus software (BECKER et al. 1992).

\section{RESULTS}

The averages of plant height of the cultivars Renan (Re), Rendez-Vous (RV), Camp-Rémy (CR) and Roazon $(\mathrm{Rz})$ scored at the Plant Breeding Station at Rennes were $91,80,93$, and $92 \mathrm{~cm}$ respectively. The parents of the $F_{2}$ populations $(\operatorname{Re} \times \mathrm{CR}$ and $\mathrm{RV} \times$ $\mathrm{Rz}$ ) were not highly contrasted in height.

\section{Mapping of Rht-B1 and Rht-D1}

The $\mathrm{GA}_{3}$ test allowed identification of the genotype for each $\mathrm{F}_{2}$ plant in both populations ( $\mathrm{Re} \times \mathrm{CR}$ and $\mathrm{RV} \times \mathrm{Rz}$ ). The two genes have been considered as genetic markers and their localisation on the maps is given in Fig. 1a and 1b. Assignation of the linkage groups to the chromosomes 4B and 4D was realised using a microsatellite (GWM165) which gave homoeologous loci on each of the three chromosomes of the group 4 (PlaschKe et al. 1996). The loci on chromosomes $4 \mathrm{~B}$ and $4 \mathrm{D}$ were both polymorphic for both $\mathrm{F}_{2}$ populations. The Rht-B1 gene was located between $X p s r 144-4 B$ and $X g l k 556-4 B$. Nevertheless, the linkage was not very strong since the gene was $13 \mathrm{cM}$ distal to the former and $43 \mathrm{cM}$ distal to the latter (Fig. 1a). On the other hand, the gene Rht-D1 was very close to $X g l k 578-4 D(3 \mathrm{cM})$, but we did not find a more distal marker beyond this gene. The level of polymorphism detected between the two parents of this cross was low (RV and $\mathrm{Rz}: 18 \%$ of polymorphic probes). This, combined with the poor polymorphism generally detected on the $\mathrm{D}$ genome (CHAO et al. 1989; CADALEN et al. 1997) can explain our result.

The marker regression method conducted on the data from the $\operatorname{Re} \times C R \quad F_{2}$ population detected the 
a

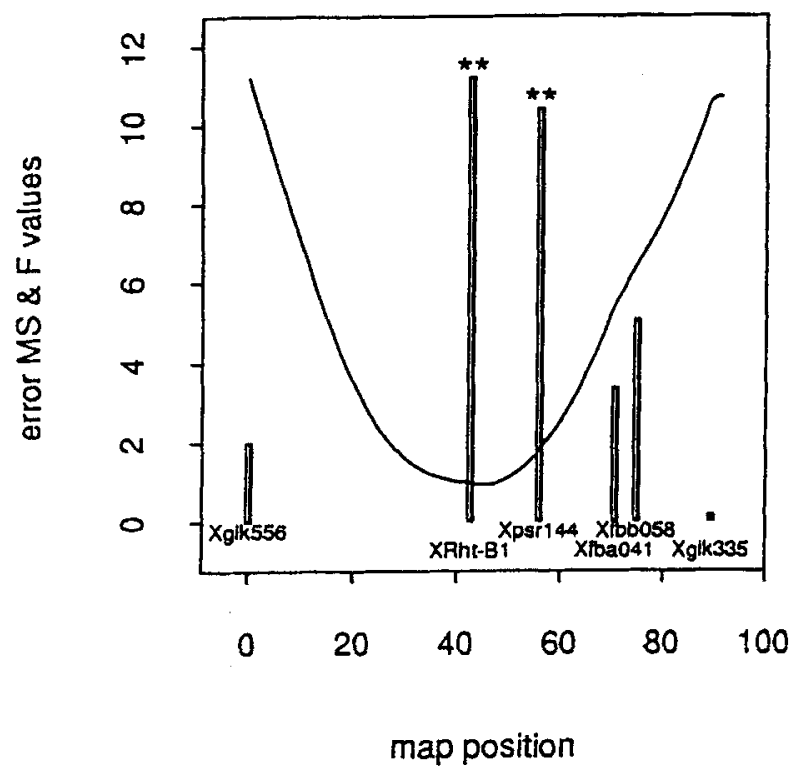

b

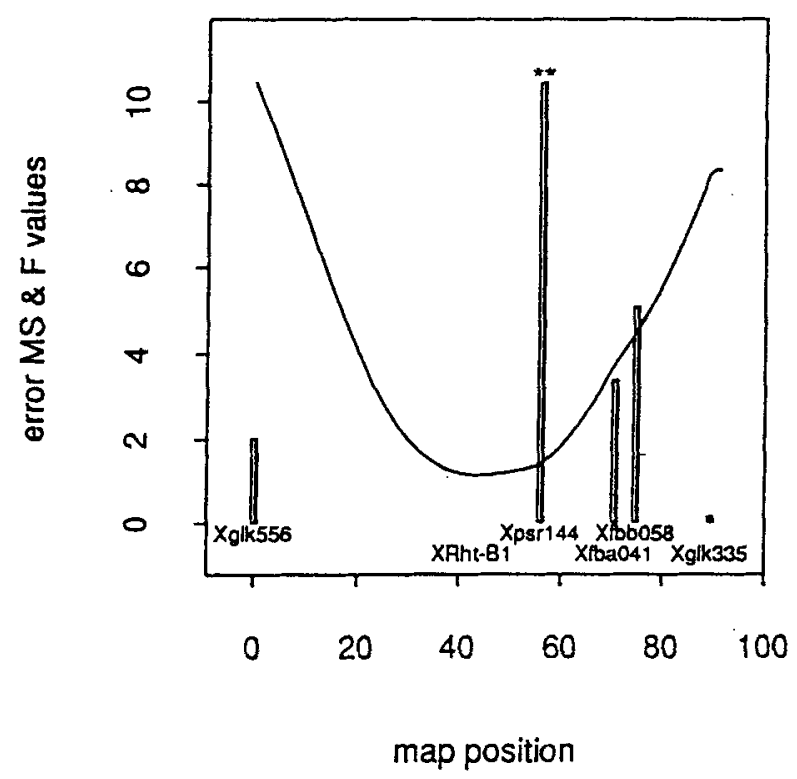

Fig. 2 a and $b$. Detection of loci associated with plant height on the $F_{2}$ population Renan $\times$ Camp-Rémy using the regression method (KEARSEY and HrNe 1994). Only partial maps (around $90 \mathrm{cM}$ long) are given. Positions of the anchor markers are given in cM along the abscissa according to Kosambi (1944). The long arm of each chromosome is toward the right of the graphics and the short arm toward the left. The origin ( 0 ) indicates the first marker of the short arm. The graphs represent the $F$ tests for each marker (vertical bars). The curve indicates the changes in residual mean square for various putative QTL positions as defined by KEARSEY and HYNE (1994).

(a) all markers, (b) when omitting $X R h t-B 1$ from the analysis.

same QTL (Fig. 2) with or without including the $X r h t-B 1$ locus in the analysis. This QTL was located at the same position in both cases. This locus explained only $9 \%$ of the variability for plant height on this population and the locus Xglk556-4B was not found to be significantly associated with this trait $(F$ probability 0.15 ). The positive allele (increasing plant height) came from $C R$, which was consistent with the fact that Re carried the $R h t-B 1 b$ allele. The additive value was $5.4 \mathrm{~cm}$ while the dominance effect was only $0.4 \mathrm{~cm}$. This result was not expected since $R h t-B 1$ was described as semi-dominant (GALE and YousSEFIAN 1985).

\section{DISCUSSION}

Molecular markers linked to dwarfing genes would allow more rational breeding schemes concerning plant height. In this study, we have found two loci (Xpsr 144-4B and Xglk578-4D) associated with two such genes ( $R h t-B 1$ and $R h t-D 1$, respectively). In the case of $R h t-B 1$, information from the two loci flanking the gene (Xpsr 144-4B and Xglk556-4B) should be necessary for integration of these molecular markers in a breeding scheme. The gene Rht-D1 was not framed between two markers. It is located on the D genome (chromosome 4D), which was often mentioned to be less polymorphic than the A and B genomes (CHAO et al. 1989; KAM-MORGAN et al. 1989; LiU and TsUNEWAKI 1991; CADALEN et al. 1997). This may explain the fact that we found only few markers on this chromosome.

It was unexpected to find so weak additive and dominance values $(5.4 \mathrm{~cm}$ and $0.4 \mathrm{~cm}$, respectively) on the $\operatorname{Re} \times C R F_{2}$ population. Perhaps, they are due to epistatic effects between $R h t-B 1$ and other regions on the genome, which reduce the effect of Rht-B1.

Two loci found to be associated with these genes were revealed by a unique microsatellite (GWM165). Microsatellites have several advantages versus RFLP markers: (1) the level of polymorphism detected is much higher (e.g., PIC values for the three loci for this microsatellite on the $\mathrm{A}, \mathrm{B}$, and $\mathrm{D}$ genomes, respectively: $0.42,0.81,0.42)$ than the level of polymorphism of RFLP (mean of PIC value 0.3); (2) each locus is genome-specific and, in our case, previous chromosome assignment done on aneuploid lines (PLASCHKE et al. 1996) allowed each linkage group to be attributed to a chromosome.

Our results should be validated on a core collection of genotypes with the probes PSR144 and GLK578. We will probably be confronted with the lack of 
polymorphism detected by RFLP probes in wheat. For example, the probe PSR144 reveals very few polymorphisms and is thus difficult to use in a breeding scheme (J SNAPE, personal communication). Microsatellites could be a way to solve this problem.

\section{ACKNOWLEDGEMENTS}

The authors wish to gratefully thank B. Charef for technical assistance, and S. Bernard for critical comments on the manuscript. We thank F. Quétier (Paris-Sud University), M. Gale (John Innes Centre), K. Tsunewaki (Kyoto University), and M. Röder (Gatersleben University) for providing the probes and the microsatellites. This work was part of the Génoblé phase II programme and was supported by the French Ministry of Agriculture and the Groupement d'Intérêt Scientifique (GIS) Génoblé including 13 French private companies.

\section{REFERENCES}

Allan RE, (1970). Differentiating between two Norin 10/ Brevor 14 semidwarf genes in a common genetic background. Seiken Zihô 22: 83-90.

Allan RE, (1983). Yield performance of lines isogenic for semidwarf genes doses in several wheat populations. In: Proc. 6th Int. Wheat Genet. Symp. (ed. S Sakamoto) Kyoto, Japan, p. 265-270.

Allan RE, Vogel OA and Craddock JC, (1959). Comparative response to gibberellic acid of dwarf, semi-dwarf, and standard short and tall winter wheat varieties. Agron. J. 51: 737-740.

Allan RE, Vogel OA and Peterson CJ, (1968). Inheritance and differentiation of semidwarf culm length of wheat. Crop Sci. 8: $701-704$.

Bassam BJ, Caetano-Anolles G and Gresshoff PM, (1991). Fast and sensitive silver staining of DNA in polyacrylamide gels. Anal. Biochem. 196: 80-83.

Becker RA, Chambers JM and Wilks AR, (1992). The new S language: A Programming Environment for Data Analysis and Graphics. Wadsworth and Brooks. Cole Advanced Books and Software. Pacific Grove, California.

Borlaug NE, (1968). Wheat breeding and its impact on world food supply. In: Proc. 3rd Int. Wheat Genet. Symp. (eds KW Finlay and KW Shepherd) Australian Acad. Sci. Canberra, Australia, p. 1-36.

Börner A and Mettin D, (1988). The genetic control of gibberellic acid insensitivity of the wheat variety Ai-Bian. In: Proc. 7th Int. Wheat Genet. Symp. (eds TE Miller and RMD Koebner) Cambridge, UK, p. 489-492.

Börner A, Worland AJ, Plaschke J, Schumann E and Law CN, (1993). Pleiotropic effects of genes for reduced height ( $R$ ht) and day-length insensitivity (Ppd) on yield and its components for wheat grown in middle Europe. Plant Breed. 111: 204-216.

Börner A, Plaschke J, Korzun V and Worland AJ, (1996). The relationships between the dwarfing genes of wheat and rye. Euphytica 89: 69-75.

Cadalen T, Boeuf C, Bernard S and Bernard M, (1997). An intevarietal molecular marker map in Triticum aestivum L. em. Thell. and comparison with a map from a wide cross. Theor. Appl. Genet. 94: 367-377.
Chao S, Sharp PJ, Worland AJ, Warham EJ, Koebner RMD and Gale MD, (1989). RFLP-based genetic maps of wheat homoeologous group 7 chromosomes. Theor. Appl. Genet. 78: 495-504.

Devos KM, Atkinson MD, Chinoy CN, Liu CJ and Gale MD, (1992). RFLP-based genetic map of the homoeologous group 3 chromosomes of wheat and rye. Theor. Appl. Genet. 83: 931-939.

Devos KM, Millan T and Gale MD, (1993). Comparative RFLP maps of the homoeologous group 2 chromosomes of wheat, rye and barley. Theor. Appl. Genet. 85: 784792.

Devos KM, Dubcovsky J, Dvorak J, Chinoy CN and Gale MD, (1995). Structural evolution of wheat chromosomes 4A, 5A, 7B and its impact on recombination. Theor. Appl. Genet. 91: 282-288.

Gale MD and Gregory RS, (1977). A rapid method for early generation selection of dwarf genotypes in wheat. Euphytica 26: 733-739.

Gale MD and Marshall GA, (1975). The nature and genetic control of gibberellic insensitivity in dwarf wheat grain. Heredity 35: 55-65.

Gale MD and Youssefian S, (1985). Dwarfing genes in wheat. In: Progress in Plant Breeding I (ed. GE Russel) Butterworth and Co, London, U.K., p. 1-35.

Gale MD, Law CN, Marshall GA and Worland AJ, (1975). The genetic control of gibberellic acid insensitivity and coleoptile length in 'dwarf' wheat. Heredity 34: 393-399.

Jia J, Devos KM, Chao S, Miller TE, Reader SM and Gale MD, (1996). RFLP-based maps of the homoeologous group 6 chromosomes of wheat and their application in the tagging of Pm12, a powdery mildew resistance gene transferred from Aegilops speltoides to wheat. Theor. Appl. Genet. 92: 559-565.

Kam-Morgan LNW, Gill BS and Muthukrishnan S, (1989). DNA restriction fragment length polymorphisms: a strategy for genetic mapping of D genome of wheat. Genome 32: $724-732$.

Kearsey MJ and Hyne V, (1994). QTL analysis: a simple "marker-regression approach". Theor. Appl. Genet. 89: 698-702.

Kosambi DD, (1944). The estimation of map distances from recombination values. Ann. Eugen. 12: 172-175.

Lander ES, Green P, Abrahamson J, Barlow A, Daly MJ, Lincoln SE and Newburg I, (1987). Mapmaker: an interactive computer package for constructing primary genetic linkage maps of experimental and natural populations. Genomics 1: 174-181.

Liu Y and Tsunewaki K, (1991). Restriction fragment length polymorphism (RFLP) in wheat. II-Linkage maps of the RFLP sites in common wheat. Jpn. J. Genet. 66: $617-633$.

Lu YH, Merlino M, Isaac PG, Staccy J, Bernard $\mathbf{M}$ and Leroy $\mathrm{P}$, (1994). A comparative analysis between $\left[{ }^{32} \mathrm{P}\right]$ and digoxygenin-labelled single-copy probes for RFLP detection in wheat. Agronomie 14: 33-39.

Marino CL, Nelson, JC, Lu YH, Sorrells ME, Leroy P, Lopes CR and Hart GE, (1996). RFLP-based linkage maps of the homoeologous group 6 chromosomes of hexaploid wheat (Triticum aestivum L. em. Thell). Genome 39: 359-366.

McIntosh RA, (1979). Catalog of gene symbols for wheat. In: Proc. 4th Int. Wheat Genet. Symp. (ed. S Ramanujam) New Delhi, India, p. 1299-1309.

McVittie JA, Gale MD, Marshall GA and Westcott B, (1978). The intra-chromosomal mapping of the Norin 10 and Tom Thumb dwarfing genes. Heredity 40: 67-70. 
Nelson JC, Van Deynze AE, Autrique E, Sorrells ME, Lu YH, Merlino M, Atkinson $\mathbf{M}$ and Leroy P, (1995a). Molecular mapping in bread wheat. Homoeologous group 2. Genome 38: 516-524.

Nelson JC, Van Deynze AE, Autrique E, Sorrells ME, Lu YH, Negre S, Bernard M and Leroy P, (1995b). Molecular mapping in bread wheat. Homoeologous group 3. Genome 38: 525-533.

Nelson JC, Van Deynze AE, Sorrells ME, Lu YH, Atkinson $M$, Bernard $M$, Leroy $P$, Faris $J$ and Anderson JA, (1995c). Molecular mapping of wheat: major genes and rearrangements in homoeologous groups 4,5 and 7 . Genetics 141: 721-731.

Plaschke J, Börner A, Wendehake K, Ganal MW and Röder MS, (1996). The use of aneuploids for the chromosomal assignment of microsatellite loci. Euphytica 89: 33-40.

Reid JB, (1986). Gibberellin mutants. In: Plant Gene Research: A Genetic Approach to Plant Biochemistry (eds AD Blonstein and PJ King) Springer-Verlag, Wien, New York, p. 1-34.

Snape JW, Law CN and Worland AJ, (1977). Whole chromosome analysis of height in wheat. Heredity 38 : $25-36$.
Sourdille P, Perretant MR, Charmet G, Leroy P, Gautier MF, Joudrier $P$, Nelson JC, Sorrels $M E$ and Bernard $M$, (1996). Linkage between RFLP markers and genes affecting kernel hardness in wheat. Theor. Appl. Genet. 93: $580-586$.

Van Deynze AE, Dubcovsky J, Gill KS, Nelson JC, Sorrells ME, Dvorak, J, Gill BS, Lagudah ES, McCouch SR and Appels R, (1995). Molecular genetic maps for group 1 chromosomes of Triticeae species and their relation to chromosomes in rice and oat. Genome 38: 45-59.

Vogel OA, (1964). Registration of Gaines wheat. Crop Sci. 4: $116-117$

Worland AJ and Petrovic S, (1988). The gibberellic acid insensitive dwarfing gene from the wheat variety Saitama 27. Euphytica 38: 55-63.

Worland AJ and Sayers EJ, (1995). Rhtl (B.dw) an alternative allelic variant for breeding semi-dwarf wheat varieties. Plant Breed. 114: 397-400.

Worland AJ, Gale MD and Law CN, (1987). Wheat genetics. In: Wheat Breeding; its Scientific Basis (ed. FGH Lupton) Chapman and Hall, New York, p. 129-171.

Xie DX, Devos KM, Moore G and Gale MD, (1993). RFLP-based genetic maps of the homoeologous group 5 chromosomes of bread wheat (Triticum aestivum L.). Theor. Appl. Genet. 87: 70-74. 